\title{
Losing the 'monopoly': A French experience of playwork practice
}

\author{
Baptiste Besse-Patin, Gilles Brougère and Nathalie Roucous * \\ april 2017
}

\begin{abstract}
This article explores the implementation of PlayPods, designed by Children's Scrapstore in the UK, in two French school playgrounds as part of an Erasmus+ project. The use of PlayPods was an innovative undertaking in France where playwork is an emerging discipline. The researchers used an ethnographic approach to examine the two settings, based on observation and focus groups with children and animateurs ${ }^{\mathrm{I}}$ to collect data. The findings include responses to the training presentation and four key issues, which were (I) the scrap material, (2) the animateurs' position, (3) conflicts among children and (4) the risks. I conclude with a discussion of the relationship between children's play and French animateurs who adopted an intermediate position between their usual practices and playwork principles.
\end{abstract}

\section{Introduction}

In February 2016, an unusual wood hut appeared next to the benches and a few trees in a paved school playground in Paris. Some days later, after the holidays, the mysterious wood hut was unlocked, letting the children see its contents, enticing them to engage with the materials. In a few minutes, the empty school playground was filled with the ebullience of sounds including games of chase and tag, and 'walk and talk' activities. A festival of the playground (SuttonSmith 1990) erupted as hundreds of scrap materials that had been contained in the hut invaded the playground.

\footnotetext{
"Laboratoire EXPERICE, Université Paris I3

'Animateurs is translated from French into English as 'supervisor', 'youth leader' or 'counsellor'. However, this doesn't aptly describe the actions of those adults who worked with the children with the PlayPod in the school playground. A more apt translation should be 'organiser', but we prefer to keep the French word, which reflects the specificity of the practice.
} 
To our knowledge, this wood hut represented the first French experiment of playwork. In fact, since the 1980 os in France, the large majority of adventure playgrounds have disappeared for many reasons, including pressure on urbanisation, neighbourhood litigations and risks (Raveneau 20I4). This article reports on the implementation of a PlayPod, originally designed by Children's Scrapstore in the UK, in two French school playgrounds in Paris. The PlayPod was introduced to the playgrounds by French animateurs. These had received training about the use of PlayPods and had interpreted playwork practices and principles during the time of the experimentation. They were key to the organisation of the opportunities for the hildren who used the materials from the 'hut in the school playground'. These French animateurs developed a hybrid practice between their usual and playwork practices.

This case study discusses how the French tradition of children's activities supervision meets playwork. First, we describe the context for the case study and then the ethnographic methodology used to observe the PlayPods. The analysis of the findings focuses on four issues: (I) the scrap material, (2) the animateurs' position, (c) conflicts among the children and (d) the risks. The article concludes with an examination of the relationship between French animateurs and children's play.

\section{Background}

The way children engage in the public space has changed over the last few decades (Christensen and O'Brien 2003; Holloway and Valentine 2004). In Western countries there have been reduced opportunities for children to play or to have independent mobility due to increasing vehicle traffic and the inherent risks of public spaces related with the fear of strangers or kidnapping. These factors contribute to trends of 'domestication' and 'insularisation' of children's lives (Zeiher 200I). Children have been confined in places such as homes, bedrooms and gardens, or they travel by car between 'child-specific institutions' for organised activities, which are more or less 'scholarised' (P. A. Adler and P. Adler 1994; Nocon and Cole 2006), under permanent adult supervision. Ironically, it is in the school playground where children are less constrained and they can play together with less supervision.

The Erasmus+ project reports the same findings:

While the time spend at the nursery, then at school and at the recreation centres are steadily increasing for children, the "outside" time decrease. The playground is often the only place where children can freely play outside. Now this is a pedagogically disinvested place, poor in games, where it reigns "chaos" and is, in fact, a very "accident-prone" and stressful place for educational teams. Meanwhile our society produces more objects and as a result, we can observe the increase of waste of all kinds: factory unsold, objects with flaws, packaging, objects that are old-fashioned...they are still poorly reused and recycled. 


\section{I.I A French specificity?}

As mentioned above, the process of childhood's institutionalisation (Zeiher 200I) is visible within the increasing children's time spend in organised childcare (Smith and Barker 2000; Valentine and McKendrick 1997). But, in France, out-of-school community or municipal childcare has a long history since the middle of the igth century, including summer camps (colonies de vacances) and out-of-school clubs (patronages) (Lee Downs 2002). According to Gram (2003), this process presents some special features: in her comparative study, adult's supervision differentiates how children's activities (6-I2 year olds) during spare time are structured. Unlike Netherlands or Germany, she concludes that children's activities are highly structured in France by adult-led agendas. Within this tradition, out-of-school clubs, leisure centres or summer camps are mainly based on supervised games and activities, and there are few opportunities in settings where children can play 'freely'. Without play policy, unlike in Wales, Northern Ireland or Scotland, the discourses and organisational policies of childcare settings include an educational dimension across extracurricular activities mostly focused on success at school (Roucous 2007).

For 18 months, six organisations from France and Spain cooperated to experiment with the PlayPod concept designed by Children's Scrapstore in the UK. The collaboration considered many concepts, including the notion of childhood and spaces for children to play. Briefly, the PlayPod contains scrap materials (recycled objects which are not manufactured toys) or "loose parts" (Nicholson 197I). It was placed on the school playgrounds and opened daily during lunchtime. Children could play with objects retrieved from the Pod or left in the playground by other children. The PlayPod project included an audit of the school playground, and training and mentoring sessions about playwork practice to order to transform the lunchtime environment of the school playground. The French team was trained as PlayPod trainers by the staff of Children's Scrapstore. (This training also included one of the researchers who authored this article.) This team then trained the animateurs who would work with the PlayPod in the school playgrounds. For the animateurs this role was different to what they had undertaken previously in the school playgrounds.

The PlayPod was renamed Boite a jouer (Playbox) in the French context, and we refer to the English translation of this to distinguish the French version from the original Scrapstore PlayPod. The research on the Playbox in French school playgrounds was not considered to be an evaluation but rather what the researchers preferred to call "a scientific support of the implementation of PlayPods." An evaluation would have needed to define beforehand what was needed to be evaluated, and it would have demanded resources (sample groups with all other factors being equal). This small- scale case study did not seek any generalisations about French animateurs or French playgrounds. However, this project allowed the researchers to make some comparisons with the playwork literature and the circumstances and scholarship about playwork in France. Thus, this research emphasises practice, what the Playbox afforded the children, its relationship to the practice of adults, and in what manner it transforms (or not) those practices (Brougère et al. 2016). 


\section{Methodology}

Evaldsson and Corsaro (1998, p. 338) argue that researchers should consider play and games as situated activities in a 'real setting' and their micro-culture with 'real children who often have long interactional histories.' Similarly, Sutton-Smith (1997, p. I20) stated that playing occurs 'in a particular social context with its own particular social arrangements.' We wanted to observe directly children's play and animateurs' interventions within their particular spaces (school playground), during specific periods (recess, holidays) and between children.

An ethnographic approach was therefore used to examine the use of the Playbox. Four ethnographic researchers were present to see and hear what was going on. It took root in the importance of the physical presence of the researcher with the people being observed: a moment of sharing, a form of participation in the situation, even if it was peripheral (Willett et al. 2013). The researchers carried out more than 60 observation sessions before and after implementing the Playbox on the two sites. These observations were at a distance from the children, but not very far from the adults who were present during the same sessions. The research participation was maintained in the margins or a peripheral participation, rather than adopting a 'least adult role' (Mandell I988) or participating in the children's activities, like Corsaro (1985). On the one hand, this permitted the researchers to distinguish themselves from the supervisors and their authority, a position that was supported by the presence of a camera and a journal of fieldnotes. Children came to discuss with the researchers about their role and their work, and also asked the researchers to take some pictures. On the other hand, the distance from the children put pressure on the animateurs as the researchers were sometimes perceived as educational experts.

\section{I Participants}

In France, two organisations (Ligue de l'enseignement, Jouer pour viure) were in charge of the project. They selected the research settings following the Children's Scrapstore diagnosis and training. The research centre (Experice from University Paris 13, Sorbonne Paris Cité) was responsible for the research part. The implantation of the French Playbox involved a Parisian elementary school, Setting A (similar context to the Children's Scrapstore model) during the lunchtime break, and Setting B, a suburban leisure centre (a kind of after-school programme during holidays), within an elementary school. In each setting, a team of animateurs independent of the normal school hierarchy supervised children during recess or holidays. The two locations chosen to carry out this system are quite different. In Setting A more than I2O children could play simultaneously in the playground. In Setting B about 20 children gathered in the playground without any concurrent activity offered, other than playing in the playground at something else other than the Playbox. The objects contained in the Playbox were similar at both sites including ropes, tyres, keyboards, phones, textiles and cable reels. A global ratio gives two scrap items per child, so there were some differences in quantity in the two boxes - around 400 objects in Setting A and 80 in Setting B. 
Another difference was when the Playbox was open. At Setting A, the Playbox was opened during the lunchtime break during school time, whereas at Setting B, it was used as a recreational support during several periods of 'free time' between programmed activities such as indoor workshops or outdoor activities run by the animateurs. This 'in-between' activities time during holidays had a more or less similar function to recess during school. However, lunchtime in Setting A was one-and- three-quarter hours, whereas in Setting B there was a succession of two or three shorter periods (around 20-30 minutes to one hour) in which the Playbox was used. Further, Setting B's context was very different to the original model, which provoked the researchers to consider some adaptations.

\subsection{Data collection}

The data collected first and foremost focused on describing what the children did with the Playboxes, as well as how the adults supervising them were involved. The researchers systematically organised their observations that were complemented with data from the focus groups. Before and after the implementation of the Playboxes, 17 focus groups were held with three or four children each of the same age as well as the team of animateurs (I3 groups at Setting A and 4 groups at Setting B). Seven focus groups were held with the three managers of the two sites. The observation and focus group data was supported by taking photos and making videos. On each site, parents had given authorisation to take pictures of their children within the framework of the centre's activities. The researchers could visually document what they saw and then study details including the many parallel interactions among the children. A film was made to support and facilitate some interviews in order to understand the meaning of the animateurs' interventions and the children's activities (C. Richards 20II). This was also used to inform parents about the research.

During the data collection process the researchers wanted to ensure that the children's consent was considered and the choice to participate or not in the research was respected (Barker and Smith 2001; Christensen and Prout 2002; Eder and Corsaro 1999; Morrow and M. Richards 1996; Thomas and O'Kane 1998). However, on one site after the first focus group, the researchers had to remind managers to let the children decide about participation in the focus groups and not conscript them to the groups. This incident reflected an authoritarian form of relations between the children and the adults that will be discussed below, about conflicts and disputes.

\section{Findings}

\section{I Responses to the training}

Jouer pour vivre carried out training for the animateurs in the two settings. The training took place in three sessions that were each 2.5 hours in duration, followed by a fourth session after the opening of the Playbox. It also included mentoring, like the Children's Scrapstore training of 
midday supervisors. In essence this training was based on the main principles from the model used by the Children's Scrapstore and playwork literature (Brown and Taylor 2008; Hughes 200r; Newstead 2004). The animateurs used the Playwork Principles (Playwork Principles Scrutiny Group 2005) and other playwork terminology concerning play such as play cycle, play cues, play return and play frame (Else 20I4; Kilvington and Wood 20IO; Sturrock and Else 1998). They were also trained to consider the мота (Move, Observe, Think, Act) principles featured in Children's Scrapstore's training handbook. This article is not able to examine the whole training process: however, of note was the animateurs' receptiveness to the training.

The aim of the training was to transform the animateurs' practice. However, due to time pressures there was no discussion or debate about the content of the training as the trainers just presented the information and documents to the animateurs. More generally, and excepting the polemic subjects (risks), some topics kept to a consensual view without destabilising or questioning taken-for-granted assumptions. In the third training session, a trainer asked the animateurs to remind themselves about two elements of the play cycle that had been presented in the session the previous week. The following conversation occurred:

One animateur answers without hesitating "set up and game rules". One trainer seems confused as the other one, who clarifies the question: "the play cycle that we talked about the last time". This time, the sound of silence is the answer. Many hazardous answers later, the second trainer cuts the attempts and replaces the concepts of "flow", "cue", "play frame". (Setting A, Observation, Training session 3, I4h49)

The spontaneous answer was typical of the usual animateurs' practices. Their practice consists of setting up the field (lines, cones) and preparing specific materials before gathering the children, explaining the goal and rules of the game, selecting the teams, and managing the game until the end. During the first training session about the importance of play, the play definition appeared quite similar between the animateurs' definition and the one proposed by the trainers. However, the practices were quite different. In other words, the definition didn't highlight the difference between adult- and self-directed play facilitated by playwork practitioners. For instance, Strandell (446 1997, see also 2000) describes how children's play 'has become a professional tool for the professional engaged in the upbringing of children', and how it is 'treated as a supervised and curricularized activity.' The same word (play) is used in the two approaches. While watching a video at the end of the first training session and being asked to play with PlayPod, an animateur said that it was "all the animateur's nightmares gathered in a same time” (Setting A, Observation, Training session I, I6h53).

\subsection{From 'nightmares' to reality}

Before the Playbox opening, almost all the animateurs were seen to sometimes engage in conversation with the children during 'free time' and lunchtime. However, they were more occupied with patrolling the playground and dealing with issues (or accidents) than engaged in any form of play. A few of them, mainly the youngest, were included in a game (dodgeball 
or football) during their patrols. Once the PlayPod opened, the ecology of the playground was profoundly modified. There was an increase in the number of objects and, consequently, the play opportunities for the children. This had an impact on the animateurs' work. The following sections examine further data from the observations and focus groups.

\subsection{Learning to cope with a lot of unusual objects}

Prior to the use of the Playboxes, the school playgrounds contained very few materials. There was a limited number of balls and skipping ropes. In both settings, some children had brought along a few personal objects (for example, Pokémon cards). However, these materials were actually banned from the playground, although on rainy days, these forbidden objects were allowed in a limited quantity. At Setting B, there were lots of play resources that were only used for specific activities. One animateur explained that, "it's about the rules too [meaning the management rules], we are not allowed to use everything, we are not allowed to..." (Setting B, Focus, Animateurs, Before opening). The intentions for and use of the resources were directed by the adults. Thomson (2014) noted that the jumping ropes must be used for jumping and not be tied together or used as reins to play 'horses'. The playground was 'territorialised' (Thomson 2005 ) into different spaces assigned to different types of play, including the football field, other ball games (dodgeball), jumping ropes or 'calm games'. The term 'ludic desert' (Bour 2007) best described the two playgrounds where children's personal objects were prohibited and the others controlled.

The animateurs' team noted that they were feeling uncomfortable about the resources in the Playboxes being in the playgrounds. The scrap material (loose parts) was intended to be used by the children without the directions of the adults. Flexible scrap materials can be used in many ways, and their use couldn't always be predicted by the animateurs. What is allowed? What is possible? Faced with the unpredictability of play, the animateurs weren't sure what the children were going to do. They were concerned about the atypical objects accessible to the children and the absence of clear rules about their use. During the training there were long debates about the risks and benefits; the animateurs' team agreed a general rule proposed by the trainers: "not to be in danger, not to put others in danger".

The animateurs in Setting A were feeling very concerned as the number of children on the playground increased in the first weeks because the Playbox opening meant the cancellation of normal organised sessions. The children referred to the animateurs as being "unemployed" while there were only five children left instead of 20 and more, depending on the weather. In fact, the animateurs were usually responsible for 275 children at lunchtime everyday. And, only three or four are responsible for the playground (around I2O-I5o children) while others are present in different places of the school for lunchtime activities (library, toy library, drawing workshop) or in the canteen for lunch in turn (6o places). When the Playbox was introduced, approximately 60 children have left activities and joined the I20-I50 children in the playground, and other children surrounded the peripheral spaces of the playground that were previously less used. As some animateurs recognised, "it was intense" and "the two hours of lunchtime 
gone so quickly" (Setting A, Observation, Training session 4, I6h47). In that sense, we can almost talk about a 'cognitive overload' (Cicourel 2004), and even the children ${ }^{2}$ recognised their new state:

Loane - '.. they are more overloaded because there are many people everywhere, because they are not enough for a bit less 300 students. And there are no animateurs everywhere, at every places, in every huts, so when there are disputes and they must arbitrate two disputes at the same time ... so now I don't see many people doing nothing, well animateurs doing nothing....'

Researcher - '... there were animateurs that did nothing before?'

Loane - '...yes, there were animateurs that were waiting and now not much.' (Setting A, Focus, Children, Year 5 , After opening)

There were notable changes in the playgrounds as they became a more flexible - or 'playable' - space (Czalczynska-Podolska 2014), with none of the previous rules and regulations, one where animateurs had less control over where and how the children could play. The next section discusses how the animateurs positioned themselves as they were unsure about their role.

\subsection{Does 'no lead' mean 'no intervention'?}

In Setting A before the arrival of the Playbox, the researchers noted that the animateurs sporadically participated in games such as football, dodgeball, kick-the-can and British bulldog. They had not observed any animateur participating in symbolic or imaginative play. In observations since the arrival of the Playbox, the researchers noted that the animateurs actually decreased their participation in the children's play, except for their involvement in football games. This withdrawal of interactions with the children was an inversion of the usual practices at the leisure centre, where the animateurs organised ll the games for the children. In Setting B, since the introduction of the Playbox, the animateurs had stopped their interactions, as the following observation attests:

Fabien (animateur) arrives in the playground, hands in his pockets, the twins make their swing alone on the structure. Fabien asks "is it solid or not?" One little girl asks "Fabien, can you tie?" He answers "No, I can't, I'm not entitled to play!" and he sets out again toward another animateur, Guillaume, who meanders ... between the huts. (Setting B, Observation, After opening, 9hr8)

The response of this animateur may seem radical, but it highlights a possible misunderstanding of the intentional activity of adults discussed during the training, that potential adulteration of play should be avoided. Some understood this concept as the absence of any intervention. Thus, some announced their boredom, criticising their position's passivity, others preferring "laissez-faire" and "do not intervene". One animateur from Setting B explains his refusal to intervene: "Yes, that's it, that's why I don't do it because they [the trainers] say 'okay, let them do exactly what they want to do', so it must be observed and that's why I haven't done it" (Setting B, Focus, Animateurs, After opening).

This non-interventionist position had also been perceived by the children, and they appear

${ }^{2}$ All the names were anonymised. 
confused by the significant differences in the animateurs' style of supervision (Setting A, Focus, Children, Year 6, After opening):

Hugo - 'We can hit each other, the animateurs are saying nothing to us.'

Artbur - 'They watch...'

Hugo - 'They are watching, in fact, a moment ago, our huts was being destroyed and some animateurs were over there, they watched: "it's okay kids, go on!"'

Researcher - '.... and what are the animateurs doing, so?'

Daphné - 'Well, they play football...'

Arthur - 'The animateurs, they watch what we do but they never take action.'

Researcher - 'Is it different from what they did before?'

Hugo - 'They are here only for watch what we do and for avoid seriously-wounded people but if anyone steals, they are doing nothing, in fact, I think that the Playbox is particularly a concept to make us self-sufficient...'

The Setting B animateurs describe their practice as withdrawal from the children's play, "we have been told that we only had to put the objects out and then, let them do, so I think we stayed in the background" (Setting B, Focus, Animateurs, After opening). In contrast, Setting $\mathrm{A}$ animateurs stated they had not changed their supervision except with greater intensity due to the presence of scrap materials and multiple activities:

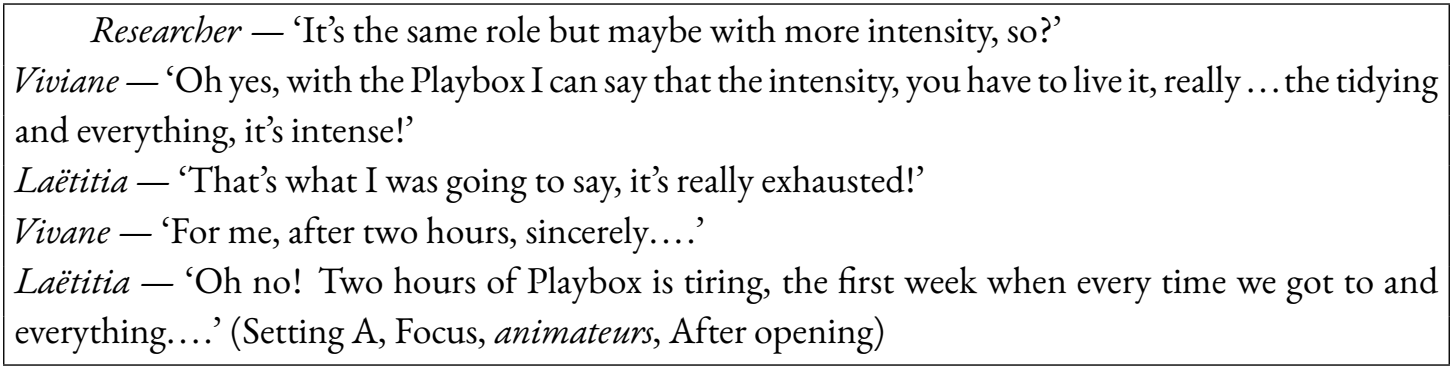

Some animateurs (four from a total of seventeen) practised differently to their peers. They participated sporadically in the play activities initiated by the children. For instance, the children created one hut as a massage parlour with all its accessories. After a period of observing the play, at the insistence of two girls, two animateurs had to comply and join in with the play. They made an appointment at the right 'office' and waited their turn before getting a massage. They didn't perceive this practice as linked to the training, but rather to their personal practices (Setting B, Focus, animateurs, After opening).

The animateurs reflected on the content of training as they linked it to their previous practices. They understood their mission as 'let play', to avoid 'adulteration' or stopping the 'play flow' (Sturrock and Else 1998), one of the points the trainers had emphasised. However, they were also reading some materials about playwork practice. They had considered the third principle of playwork (Playwork Principles Scrutiny Group 2005), and so were also trying to stop themselves from taking action, and abstained from facilitating and supporting the 'play process'. If they had had a chance for additional playwork practice training, they may have been less constrained in their practice. The training had not included information about the 
Playwork Principles or 'loose parts' theory (Nicholson 197I). If they had had more information about playwork practice, they may have been able to introduce indirect forms of intervention by environmental modification, for example (Hughes 20or; Maxwell, Mitchell, and Evans 2008; Sutton 2014).

\subsection{Less conflicts but more disputes?}

The animateurs stated that conflicts between the children had decreased. This was in contrast to the comments in the children's focus groups where they said that there were always disputes. The animateurs differentiated the latent and regular conflicts of some boys in each setting with the (little) disputes generated by the scrap material. This is summarised by animateurs Thomas and Virginie at two different times in Setting A:

Thomas - 'I think that it's rather positive, there are less conflicts, less wounded children ... so finally, there are others conflicts, there is a management, due to the games [scrap] that they pinch between them and that staff. But anyway it will be conflicts every time in a playground, so that's not problematic.' (Setting A, Focus, Animateurs, After opening, April)

Virginie - 'And even outside of the Playbox, there are less conflicts.'

Thomas - 'Less conflicts full stop. We reprimand less children, we have less problems.' (Setting A, Focus, Animateurs, After opening, June)

The conflict resolution strategies used after the introduction of the Playbox were similar to the ones used prior to the opening of the Playbox and training. The animateurs resolved disputes directly referring to the usual principles of equality - "first arrival will get the best stuff" - and shouted at the children with expressions such as "we share", "this is owned by everyone", "he got it first, so let him have it. The animateurs didn't adjust their physical positions, nor did they respond to recognising the children's states of mind and feelings, and nor did they listen to the different 'versions' of an issue. These practices were in marked contrast to the protocols recommended during training, based on open-ended questions and an adjusted position (crouching at the children level, speak quietly, understanding tone) and the principle of asking the children themselves for solutions. The animateurs justified not using the recommended strategies by saying that it was impossible in the time they had (Setting A, Observation, Training session 4, After opening), and that this method with their children would be ineffective.

Alexandre stated:

'I did take action in one case, there was a conflict between Anatole and a little child, so I stepped in and "this object, you've had it since when?" So he says to me "but I would like to play with it" so I say "you play a little more, 5 minutes and then you give him the object" and [a trainer] says me "couldn't you ask them how to resolve that conflict?" So, considering the number of children that we had, there was no problem, there was no mess, so I said "yes, it's true, I could have done it like that" only there, with 50 children, because she told me "we, we try that children resolve these things by themselves, that we come just with questions so they can answer them..." and I say "yes, but not 
when there are so children”.' (Setting A, Focus, animateurs, After opening)

There were differences in the way the Playboxes were made available to the children. Even the process of tidying up at the end of a session or the end of the day had an impact on the children's opportunities for play. At Setting B in the leisure centre there were multiple opening times throughout the day, and this had an impact on the daily tidying up. The Playbox was used between $8 \mathrm{am}$ and 9am, then II.30am to I2.I5am and after lunchtime from I.30pm to 2.3opm. Initially the materials were tidied up after each use, but then this stopped. At Setting A, the distribution of objects was guaranteed - arrangements were made to ensure that the children got a chance to play with the materials at a later stage. Sometimes there was a strategic tidying up of the desired objects to ensure they were available to certain children at another session. It was observed that without the 'reset' of materials, the same children had the same resources. For example, a group led by the oldest girl monopolised and stockpiled a large number of objects to build a hut that was reproduced consecutively for several days. Other groups of children encountered difficulties using and playing with the remaining objects. With less objects (and particularly the coveted ones) there were less possibilities of combinations and arrangements, so less opportunities to play. Consequently, the absence of a 'reset' provoked some tensions between the children. Some were not able to access the objects, or they used 'sneaky' strategies to get access to them.

\subsection{Handling (the fear of) risks}

Supervision of the children by the animateurs increased, driven by fear of accidents. The introduction of risks through increased objects in the playgrounds was tolerated, but it appeared to increase the emotional strain in the animateurs' work. They noted that their work was more intense and tiring than usual due to this increased vigilance - the playground was no longer structured by a master framework to make supervision easier. One animatrice, Virginie, stated that she experienced "panic moments" related to the increased intensity of supervision (Setting A, Focus, Animateurs, After opening). She received support from her team with an exchange of visual cues helping her to "breathe". The Setting B animateurs stated that they accepted new practices from the children:

Alexandre - 'Maybe we have let them more than we use to, we have been less on their back than we use to when they did balance trick, on cardboard tube with the foam thing, and the swings too, yes, I think that before we hadn't....'

Aurélie - 'The swings, normally, the jumping ropes, they don't have the right to ... so we have let the right to, but when they tie them we must be there, because Orlane, she is never afraid and sometimes she climbs.'

Researcher - 'So in fact, the children have taken more risks than they used to, anyway, and you let them do it?'

Alexandre - 'Oh yes, yes, yes, totally!' (Setting B, Focus, Animateurs, After opening)

This acceptation has leant on a new rules set established in order to supervise the use of 
some of the objects overstepping the general rule ("not to be in danger, not to put others in danger"). For example, in relation to the use of the particularly feared jumping ropes, it was decided that the animateurs would check any knotting of the ropes. Rolling objects, such as pushchairs and wheelchairs, were forbidden to be used in chasing games. The children noted "we cannot run with the pushchairs. We really love to run, but Pascale, when she sees us, she says us 'no"' (Manon, Year 6, Setting A, Interview, After opening). Contrasting with the animateurs point of view above, some children in the focus group have expressed, in a more sensitive way than animateurs, others and new rules that seemed established sporadically without being discussed or adapted. Moreover, they were able to do a detailed list, particularly at Setting A. For instance, Théo said: "Because Olivier, he invents rules every time. Many others invent rules. In fact, if you do something that is maybe a little bit dangerous with your stick and then he arrives, 'Oh you don't have the right to...!' and you don't know really what you don't have the right to do" (Setting A, Focus, Children, Year 6, After opening).

On one hand, the new rules were imposed by the animateurs and it altered the way in which the children used the loose parts. On the other hand, the animateurs could tolerated a more risky play initiated by the children, and continued their daily supervision without supporting or facilitating the children's practices. This arrangement was a way to handle 'some forms of playing give rise to great anxiety for the adults responsible' (Lester, Jones, and Russell 20II, p. 46). This anxiety for the children's safety was linked to parental pressure, fears of critics including the management of the settings, and possible litigations.

\section{Discussion}

Since the introduction of the Playboxes, play types (Hughes 200I) increased significantly. For example, imaginative play in huts, exploratory play, motor play with manufactured swings and children involved in complex play frames were observed. Loose parts in the Playboxes were 'a formidable ingredient for enabling children to engage in play' (ibid., p. 229). The evolution of play opportunities was noteworthy. Armitage (2010, p. 52) states that, ' $[\mathrm{t}] \mathrm{he}$ provision of opportunities to play, in mixed age groups and with an apparent lack of adult involvement, is classic playwork', and this description can be applied to the introduction of the Playboxes in Settings A and B. However, it could also be noted that this evolution was realised despite the animateurs.In each setting, an animateur used the term 'monopoly' to talk about change in their practices. The French animateurs in this study fluctuated between simply supervising without intervening in the children's play, except to reprimand or resolve disputes, and joining in a game on the children's request. The children's play was no longer in the animateurs' hands; they couldn't manage or control objects or steer their uses.In Setting B the Playbox was opened in an 'activities-based centre' where children were free to chose from the games and activities organised and supervised by the animateurs. In this setting there was a 'wait and see' approach to see what the children would chose to do from the selection provided. The Playbox hasn't been affected by what is considered to be the 'core business' of 
the animateurs - 'doing activities'. It was inserted between or next to the workshops, and was just an additional element among others from which the children could choose. It offered new possibilities in 'free time' next to the usual supervised play:

Researcher - 'Would you have had an inclination toward taking distances from what the [project and training] proposed, would you have been more inclined to take action more often? Aurélie - 'We, when we opened the Playbox, it was in lunchtime, so that means that it was the time for us to take a break and so we don't have much time to be with the children and while the Playbox was open. Because then, in the evening, there were less and less children, it was one hour and the weather, sometimes, didn't help us. We really have had many...' (Setting B, Focus, Animateurs, After opening)

Considering the breaks after lunchtime and the little free time subject to the weather, Aurélie described how they didn't feel like they had the opportunity to engage with the Playbox project. Moreover, they were replaced by other animateurs to take a break before activities resumed. Consequently, most of the animateurs adopted the same practices they had before. The Playbox introduced some risks, and so their main mission of supervision remained the same. Hence, during the experimentation with the Playboxes, the animateurs couldn't adopt other practices to give alternative support to the children's play.

The strategies used by playwork practitioners aren't easy for beginning practitioners. It was even harder for the animateurs who found the strategies to support children's play with the Playboxes contradicting their usual responsibilities. The 'wait and see' approach as interpreted by the French animateurs didn't match the intentions of playwork practice. However, they reported that by staying in the background and observing, they were surprised at the children's practices and abilities. They were especially surprised by the reduction in conflicts between the children and the need for them to punish the children during play sessions. French animateurs are not trained to follow children's agendas and initiatives. However, in these research settings with the Playboxes, they adopted an intermediate position, combining some playwork practices when they let the children play with scrap material without any support or facilitation with patrolling the playground and reminding the children about the rules.

\section{Acknowledgements}

The authors would to thank gratefuly the reviewers for their improving comments and the editor's team for their helpful support. 


\section{References}

Adler, P. A. and P. Adler (1994). "Social Reproduction and the Corporate Other: The Institutionalization of Afterschool Activities”. In: Sociological Quarterly 35.2, pp. 309-328. DoI: 10.1111/j.1533-8525.1994.tb00412.x.

Armitage, M. (2010). Play Pods in Schools: An Independent Evaluation (2006-2009). Project 43. London: PlayPeople, p. 60.

Barker, J. and F. Smith (200I). "Power, Positionality and Practicality: Carrying out Fieldwork with Children”. In: Ethics, Place ES Environment 4.2, pp. I42-I47. DoI: 10 . 1080 / 713665949.

Bour, Y. (2007). "'Jeux dangereux’ entre adolescents. Culture juvénile, institution scolaire et société du risque”. In: Éthnologie française 37.4, pp. 631-637.

Brougère, G. et al. (2016). Une boîte pour jouer : pratiques et discours autour d'objets recyclés. Rapport d'évaluation. Paris: Université Paris I3 - Sorbonne Paris Cité, p. I28.

Brown, F. and C. Taylor, eds. (2008). Foundations of Playwork. Maidenhead: Open University Press. 316 pp.

Christensen, P. M. and M. O’Brien, eds. (2003). Children in the City: Home, Neighbourbood and Community. London: Routledge. 21o pp.

Christensen, P. M. and A. Prout (2002). "Working with Ethical Symmetry in Social Research with Children”.In: Childhood 9.4, pp. 477-497. Dor: 10.1177/0907568202009004007.

Cicourel, A. V. (2004). "Cognitive Overload and Communication in Two Healthcare Settings". In: Communication ES Medicine I.I, pp. 35-43. Dor: 10.1515/come. 2004.004.

Corsaro, W. A. (1985). Friendship and Peer Culture in the Early Years. Norwood: Ablex. 336 pp.

Czalczynska-Podolska, M. (20I4). "The Impact of Playground Spatial Features on Children's Play and Activity Forms: An Evaluation of Contemporary Playgrounds' Play and Social Value”. In: Journal of Environmental Psychology 38 , pp. I32-I42.

Eder, D. and W. A. Corsaro (1999). "Ethnographic Studies of Children and Youth. Theoretical and Ethical Issues". In: Journal of Contemporary Ethnography 28.5, pp. 520-531. Dor: 10.1177/089124199129023640.

Else, P. (2014). Making Sense of Play: Supporting Children in Their Play. Maidenhead: Open University Press. 216 pp.

Evaldsson, A.-C. and W. A. Corsaro (1998). "Play and Games in the Peer Cultures of Preschool and Preadolescent Children: An Interpretative Approach”. In: Childhood 5.4, pp. 377-402. DOI: $10.1177 / 0907568298005004003$.

Gram, M. (2003). Grounds to play. Culture-specific ideals in the upbringing of children in France, Germany, and the Netherlands. New York: Peter Lang. 3II pp.

Holloway, S. L. and G. Valentine, eds. (2004). Children's Geographies: Playing, Living, Learning. 2nd ed. London: Routledge. 255 pp.

Hughes, B. (200I). Evolutionary Playwork and Reflective Analytic Practice. London: Routledge. 294 pp. 
Kilvington, J. and A. Wood (2010). Reflective Playwork: For All Who Work with Children. London: Continuum. I83 pp.

Lee Downs, L. (2002). Childhood in the Promised Land: Working-Class Movements and the Colonies De Vacances in France, I880-1960. Durham: Duke University Press. 4II pp.

Lester, S., O. Jones, and W. Russell (20II). Supporting School Improvement Through Play: An Evaluation of South Gloucestershire's Outdoor Play and Learning Programme. London: Play England, p. 63.

Mandell, N. (1988). “The Least-Adult Role in Studying Children”. In: Journal of Contemporary Ethnography i6.4, pp. 433-467.

Maxwell, L. E., M. R. Mitchell, and G. W. Evans (2008). "Effects of Play Equipment and Loose Parts on Preschool Children's Outdoor Play Behavior: An Observational Study and Design Intervention". In: Children, Youth and Environments 18.2, pp. 36-63.

Morrow, V. and M. Richards (1996). "The Ethics of Social Research with Children: An Overview”. In: Children ES Society I0.2, pp. 90-IO5. DOI: 10.1111 / j . 1099 - 0860. 1996. tb00461.x.

Newstead, S. (2004). The Buskers Guide to Playwork. In collab. with C. Bennett. Eastleigh: Common Threads Publications. 70 pp.

Nicholson, S. (1971). “The Theory of Loose Parts: How not to Cheat Children”. In: Landscape Architecture 62, pp. 30-34.

Nocon, H. and M. Cole (2006). "School's invasion of "after-school”: colonization, rationalization, or expansion of access?” In: Learning in Places: The Informal Education Reader. Ed. by Z. Bekerman, N. Burbules, and D. Silberman-Keller. New York: Peter Lang, pp. 99-I2I.

Outdoor Games and Sustainable Development in Educational Structures (2014). Erasmus+ Project. Paris: Ligue de l'enseignement.

Playwork Principles Scrutiny Group (2005). Playwork Principles Held in Trust as Honest Brokers for the Profession.

Raveneau, G. (2014). “L'expérience Des Terrains d'aventure En France Dans Les Années 19701980, Une Aventure sans Lendemain ?” In: Des lieux pour l'éducation populaire : conceptions, architecture et usages des équipements depuis les années 1930. Paris.

Richards, C. (20II). "In the Thick of It: Interpreting Children's Play”. In: Ethnography and Education 6.3, pp. 309-324. Dor: 10.1080/17457823.2011.610582.

Roucous, N. (2007). "Les loisirs de l'enfant ou le défi de l'éducation informelle”. In: Revue française de pédagogie 160, pp. 67-73.

Smith, F. and J. Barker (2000). "Contested Spaces Children's Experiences of Out of School Care in England and Wales”. In: Childhood 7.3, pp.315-333. Dor: 10 .1177/0907568200007003005.

Strandell, H. (1997). "Doing Reality With Play: Play as a Children's Resource in Organizing Everyday Life in Daycare Centres”. In: Childhood 4.4, pp. 445-464. Dor: 10 . 1177 / 0907568297004004005. 
Strandell, H. (200o). "What Is the Use of Children's Play: Preparation or Social Participation?" In: Early Childhood Services: Theory, Policy and Practice. Ed. by H. Penn. Buckingham: Open University Press, pp. 147-157.

Sturrock, G. and P. Else (1998). “The playground as therapeutic space: playwork as healing”. In: IP A/USA Triennial National Conference. Play in a Changing Society: Research, Design, Application. Colorado.

Sutton, L. (2014). “Adventure Playgrounds and Environmental Modification: A Beginner's Guide”. In:Journal of Playwork Practice I.2, pp.2II-2I7. DOI: 10 .1332/205316214X14111202320739.

Sutton-Smith, B. (1990). "School Playground as Festival”. In: Children's Environments Quarterly 7.2, pp.3-7. DOI: $10.2307 / 41514725$.

- (1997). The ambiguity of play. Cambridge: Harvard University Press. 276 pp.

Thomas, N. and C. O’Kane (1998). "The Ethics of Participatory Research with Children”. In: Children ES Society I2.5, pp. 336-348. DoI: 10.1111/ j.1099-0860.1998. tb00090.x. Thomson, S. (2005). “Territorialising' the Primary School Playground: Deconstructing the Geography of Playtime”. In: Children's Geographies 3.I, pp. 63-78. DoI: 10 . 1080 / 14733280500037224.

- (2014). “'Adulterated Play': an Empirical Discussion Surrounding Adults' Involvement with Children's Play in the Primary School Playground". In: Journal of Playwork Practice I.I, pp. 5-2I.

Valentine, G. and J. McKendrick (1997). “Children's Outdoor Play: Exploring Parental Concerns About Children's Safety and the Changing Nature of Childhood”. In: Geoforum 28.2, pp. 219-235.

Willett, R. et al., eds. (2013). Children, Media and Playground Cultures. Ethnographic Studies of School Playtimes. Palgrave Macmillan. 28r pp.

Zeiher, H. (20oI). "Children's Island in Space and Time: The Impact of Spatial Differentiations on Children's Ways of Shaping Social Life". In: Childhood in Europe: Approaches, Trends, Findings. Ed. by M. du Bois-Reymond, H. Sünker, and H.-H. Krüger. Rethinking childhood I5. New York: Peter Lang, pp. 139-I59. 